\title{
Sectarianism, State Failure and the Radicalization of Sunni Jihadist Groups
}

\author{
Anthony N. Celso* \\ Professor, Department of Security Studies and Criminal Justice at Angelo State University in San, Angelo \\ Texas, USA
}

\author{
*Corresponding Author: Anthony N. Celso, Professor, Department of Security Studies and Criminal \\ Justice at Angelo State University in San, Angelo Texas, USA
}

\begin{abstract}
This article aims to connect sectarian hatreds, failed states, and Islamic eschatology to the growing extremism within the Sunni jihadist movement. It comprises four interrelated themes. First, it provides an overview of the ideological currents (Iranian Shia revolutionary doctrine and Sunni jihadism) that contribute to sectarian conflicts raging across much of the Arab Middle East. Second, the article examines the impact of the 2003 U.S. directed Iraq war and the 2011 Arab Spring revolts that have aggravated intra-confessional animosities gripping the Mideast. Third, the article assesses the role of apocalyptic sentiments in accelerating intra-confessional violence in the Muslim world. Fourth, the essay relates these developments to greater extremism among Sunni jihadists whose fratricidal violence is selfdefeating yet difficult to combat.
\end{abstract}

Keywords: Jihad, Extremism, Failed States, Sectarianism and Terrorism

"The Rafidah [Shi'ites] hate Islam just as the Jews hate Christianity. They did not enter Islam longing for Allah, or fearing Him, rather out of spite for the people of Islam, and so to inflict harm upon them".

\section{INTRODUCTION}

Religious factors as a source of political conflict in the Mideast have commonly been denied by Western academics. ${ }^{2}$ Many early studies of jihadi terrorism debunked the role of religion as a driving force. ${ }^{3}$ Given the jihadist movement's resilience academic researchers are increasingly acknowledging the relevance of theological motivations as a source of political violence. ${ }^{4}$

Fuelled by religious extremism jihadi revolts have convulsed the Muslim world throughout Africa, the Mideast and Central Asia. Islamist insurgency across the world is not only growing but becoming more lethal. Islamic terrorism in 2015 killed 150,000 people with Boko Haram, the Islamic State, Al Qaeda and the Taliban accounting for $74 \%$ of these deaths. ${ }^{5}$ Sectarian driven killings of Christians,

\footnotetext{
${ }^{1}$ Dabiq 13: The Rafidah: From Ibn Saba to the Dajaal accessed at: http://clarionproject.org/wpcontent/uploads/Issue-13-the-rafidah.pdf 33

${ }_{2}$ Bale J., "Denying the Link between Islamist Ideology and Jihadist Terrorism: Political Correctness Undermining Counterterrorism" Perspectives on Terrorism 7:5 5-46; Craig Whiteside, "A Pedigree of Terror: the Myth of Baathist Influence in the Islamic State Movement" Perspectives on Terrorism 11:3

${ }^{3}$ PapeR., "The Strategic Logic of Suicide Terrorism" American Political Science Review 97:3 343361:Speckhard A., Talking to Terrorist: Understanding the Psych-social Motivations of Militant Jihadi Terrorists, Mass Hostage Takers, Suicide Bombers and Martyrs (Advances Press: 2012)sSageman M., Understanding Terrorist Networks ( Philadelphia: University of Pennsylvania, 2006)

${ }^{4}$ Moghadan A., "Salafi Jihad as a Religious Ideology" CTC Sentinel, (February 2008) Vol. 1, Issue 3; Bunzel C., "From Paper State to Caliphate: The Ideology of the Islamic State" The Brookings Project on U.S. Relations with the Muslim World Analysis Paper/ No. 19, March 2015: Bale J., "Islamism and Totalitarianism" Totalitarian Movements and Political Religions (June 2009) 73-96; Ghabadzeh N. and Kbarzadea S.A., "Sectarianism and the Prevalence of "othering" in Islamic Thought" Third World Journal 36:4 691-704

5 "Global Terrorism Index 2016" Institute For Economics and Peace 4 accessed at: http://economics andpeace.org/wp-content/uploads/2016/11/Global-Terrorism-Index-2016.2.pdf
} 
Yazidi and heterodox Muslims (Shia, Sufis, Druze and Alawites) have risen dramatically. ${ }^{6}$ Historically opposed to sectarianism, Al Qaeda (AQ) is increasingly adopting an anti-Shia ideological discourse. ${ }^{7}$ Belying its reputation as a moderate jihadi group, AQ's former affiliate (Jabhat al-Nusra$J N)$ in Syria massacred Druze communities. Throughout its history Nigeria's Boko Haram has slaughtered Christians. ${ }^{8}$

Other factors, however, mix with religion. Abetted by political and economic forces jihadi groups have exploited the weakness of the Mideast state system that saw during the Arab Spring three once strong states fall. Violent Islamist networks, moreover, have their own psychological, organization and group dynamics. ${ }^{9}$ Leadership disputes, ideological differences and personal rivalries can often produce schisms in extremist terrorist networks.

Al Qaeda, for example, has fragmented into an unwieldy network of affiliates impervious to central control. ${ }^{10}$ In his Abbottabad letters Osama bin Laden openly lamented the sectarian and near enemy fixation of his Maghreb, Somali, Iraqi and Yemeni "branches". ${ }^{11}$ One of these "affiliates" today reconstituted as the Islamic State (IS) has mounted a vigorous challenge to AQ's leadership of the global jihadist movement. Motivated by sectarian animus IS's attacks on Sufis, Christians, Yazidi and Shia Muslims has invited worldwide condemnation. ${ }^{12}$

Though political, economic, organizational and psychological factors merge with religious orientation, the end point for all jihadi groups is forcibly implanting a genuine Islamic state faithful to Mohammad and his successors rule. The complex pastiche of forces influencing jihadi groups is difficult yet not impossible to disentangle. Despite their differences and divisions they all fixate on Islamic governance.

The sectarian focus of jihadi groups has been exacerbated by political forces. Now the force of events linking sectarianism with political upheaval is difficult to deny. Fabrice Balanche'sSyrian civil war study underscores its long neglected sectarian foundations. ${ }^{13}$ Significantly the greatest generators of violence in the Mideast are in religiously stratified countries like Iraq, Syria, and Yemen.

The clashes between extremist Shia and Sunni groups across the Mideast have been building for a generation. Today Iranian financed and armed Shia radicals and Gulf Arab supported Sunni Salafist jihadists are pitted against each other in the killing fields of Syria, Iraq, and Yemen. ${ }^{14}$ Hezbollah and Shia militias have fought pitched battles against Al Qaeda and the Islamic State across the Levant. Iranian propaganda rails against Saudi supported takfiri groups and they have financed and armed Yemeni Houthi rebels fighting Al Qaeda in the Arabian Peninsula (AQAP) and United Arab Emirate and Saudi forces in that beleaguered country.

\footnotetext{
${ }^{6}$ A Call for Accountability and Protection: Yazidi Survivors of Atrocities Committed by ISIL" Office of the United Nations High Commissioner for Human Rights United Nations Assistance Mission for Iraq-Human Rights Office August 2016 accessed at http://ohchr.org/Documents/Countries/IQ/UNAMIRport12Aug2016 _en_pdf.

${ }^{\overline{7}}$ Gohel S.M.,"Deciphering Aymenn al-Zawahiri and Al Qaeda's Strategic and Ideological Imperatives" Perspectives on Terrorism 11:1 54-65

${ }^{8}$ Celso A., "Boko Haram and the Islamic State: Fifth Wave Islamist Terror Groups", Orbis 59:2 249-267

${ }^{9}$ B. Fishman and A. Moghadan., "Chapter 10: Do Jihadi and Islamist Divisions Matter: Implications for Policy and Strategy" in Moghadam A. and Fishman B. (editors), Self-Inflicted Wounds: Debates and Divisions in alQaida and its Periphery (West Point: Combating Terrorism Center, 2010)

${ }^{10}$ Celso A.,Al Qaeda's Post 9-11 Devolution: The Failed Jihadist War against the Near and Far Enemy (New York: Bloomsbury, 2014); Mandelsohn B.,The Al Qaeda Franchise: The Expansion of Al Qaeda and its Consequences ( New York: Oxford University Press, 2016)

${ }^{11}$ Lahoud N., Caudill S., Collins L., Koehler-Derrick G., Rassler D. and al-'Ubaydi M.,Letters from Abbottabad" Combatting Terrorism Center at West Point Harmony Program accessed at: https://ctc.usma.edu/posts/letters-from-abbottabad-bin-ladin-sidelined

${ }^{12}$ Office of the United Nations High Commissioner for Human Rights United Nations Assistance Mission for Iraq, ibid

${ }^{13}$ Balanche F., "Sectarianism in Syria's Civil War" The Washington Institute for Near East Policy 2018 accessed at: http://www.washingtoninstitute.org/uploads/Documents/pubs/SyriaAtlasCOMPLETE-3.pdf 16

${ }^{14}$ ZelinA. and Smyth P., (2014), "The Vocabulary of Sectarianism" January 29, 2014 The Washington Institute for Near Eastern Policy accessed at http://washingtoninstitute.org/policy-analysis/view/the-vocabulary-ofsectarianism
} 
1979 began this convergence of forces that have brought us the calamites of the Arab World's civil wars. A year noted by David Rapoport as the advent of a theologically inspired fourth wave of terror that shows no sign of abating. ${ }^{15}$ Though it inspired harsh criticism at the time Rapoport's fourth wave of religious terror is an appropriate prism upon to which conceptualize the bloody sectarian antagonisms gripping Iraq, Syria and Yemen.

Rapoport argues the confluence of the Iranian Revolution, the seizure of the Grand Mosque in Mecca by anapocalyptic cult and the mujahidin jihad against Soviet occupiers in Afghanistan began in 1979 an enduring wave of religious (mainly Islamist) terror. He speculates that the theological fanaticism that extremist Islamic visions generate make its wave more resilient than its three predecessors. The $19^{\text {th }}$ century anarchist first wave and its $20^{\text {th }}$ century anti-colonial and left revolutionary successors lacked the ideological dynamism to propel their movements for more than a generation.

Though the fourth wave began in 1979 it has grown in virulence and is spreading across the Islamic World. The ideas expressed in these events now dominate Mideast conflict and are propelling the region toward more violent encounters. This is especially true regarding apocalyptic ideology that drives Sunni and Shia to butcher each other across the region. ${ }^{16}$ Both groups see the current period as fitnah or a prophesied state of intra-Muslim conflict that precedes the rise of the Mahdi and the end of the world. Apocalyptic ideology is one of the core foundations of the Islamic State that see its adherence to prophetic methodology as a source of its legitimacy. ${ }^{17}$

\section{MATERIALS AND MethodS}

This article aims to connect sectarian hatreds, failed states, and Islamic eschatology to extremism within the Sunni jihadist movement. It comprises four interrelated themes. First, it provides an overview of the ideological currents (Iranian Shia revolutionary doctrine and Sunni jihadism) that contribute to sectarian conflicts raging across much of the Arab Middle East. The present state of discord is reminiscent of past historic conflicts and animosities that convulsed the Muslim world in its early development. The Kharajite rebellions against Muhammad' successors and the schism between the partisans of Ali (today's Shia) and those faithful to his adversary Uthman (present day Sunnis) have continually resurfaced across Islamic history. ${ }^{18}$

The tragic historical legacy of Shi'ism is commemorated by its adherents by venerating Ali and his son Husain whom were assassinated. The brutal persecution of Ali and his familial line gave birth to a culture of martyrdom and ritualistic ceremonies venerating grave sites, historic battles and Ali's family. ${ }^{19}$ The Shia observation of Ashura commemorates the death of Ali's son Husayn in the battle of Karbala highlighted by bloody rituals of groups of worshipers who beat themselves with chains. Spread over Iran and Iraq Shia majorities were persecuted by Sunni and colonial authorities. ${ }^{20}$

Such overt displays of veneration for Ali and his family are viewed by Sunni fundamentalists as shirk or polytheism that violates the core foundations of Islam. ${ }^{21}$ The accordance Shia give to clerical interpretations of Islamic tradition outside the Qur'an is similarly viewed by Sunni extremists as bidah or heretical innovations that violate past practice of the faith. ${ }^{22}$ Tehran's support for Shia aligned groups in Iraq, Syria. Lebanon and Yemen has inflamed sectarian passions across the Mideast.

15 D. Rapoport., "The Four Waves of Modern Terrorism" in J. Horgan and K. Braddock (eds), Terrorism Studies: A Reader ( New York: Routledge, 2012)

${ }^{16}$ Helfont, S., "The Geopolitics of the Sunni-Shia Divide" FPRI Footnote December 2013 access at http://www.fpri.org/doc/Helfont_-Hi_-_Sectarianism.pdf; ;HydemannS., "The Syrian Uprising: Sectarianism, Regionalization and State Order in the Levant" Fride and Havos Working Paper No. 119 (May 2013) 1-19 access at http://www.firda.org/descarga/WP_119_Syria_Uprising.pdf; Zelin A. and Smyth P., "The Vocabulary of Sectarianism", ibid

${ }^{17}$ Ryan,MWS., "Dabiq: What the Islamic State's New Magazine Tells us about Their Strategic Direction. Recruitment Patterns and Guerilla Doctrine", Jamestown Terrorism Monitor accessed at http://www. jamestown.org

${ }^{18}$ Karsh, E, Islamic Imperialism: A Short History ( New Haven:Yale University Press, 2006)

${ }^{19}$ Nasr, V., The Shia Revival: How Conflicts within Islam will Shape the Future ( New York: W.W. Norton, 2006)

${ }^{20}$ Ibid

21 "Dabiq 13: The Rafidah From IbnSaba to Dajjal", ibid

${ }^{22}$ Ibid 
The expansion of Iranian power in the region has been met with growing extremism among Sunni jihadists and this development has been exacerbated by recent political events.

Secondly, the article examines the impact of the 2003 U.S. directed Iraq war and the 2011 Arab Spring revolts that have aggravated intra-confessional animosities gripping the Mideast. They have also provided Shia Iran and Sunni jihadist groups a strategic opening to pursue their rival agendas. Loosely connected the Iraq War and the Arab Spring revolts have catalysed pre-existing sectarian animosities expanding Iranian influence in the region and accelerating the growth of more radical Sunni jihadist movements who increasing emphasize their sectarian animus toward Iran, the Shia and aligned minorities

Thirdly, the article assesses the role of apocalyptic sentiments in accelerating intra-confessional violence in the Muslim world. These sectarian tensions have raised issues of fitnah a period of internal conflict within the Muslim world that presage an apocalyptic conflict with the Western world. As Jean Pierre Filiu notes Shia and Sunni millenarian groups tie this internal conflict to western centred and Judeophobic conspiracy theories where their Muslim opponents are the lackeys of America and Israel. ${ }^{23}$ Islamic State and Al Qaeda ideologues increasingly speak of a Zionist-Crusader-Magi [Iranian] conspiracy. ${ }^{24}$

What these three developments make clear is that the Sunni and Shia radicals have progressed toward a total war doctrine that merges near, far and sectarian enemies. ${ }^{25}$ Teheran sees the growth of Sunni jihadist movements as a direct consequence of Washington and Jerusalem efforts to divide the Muslim world. Sunni jihadists and Shia radicals see that the defeat of their sectarian enemies as a transitional stage toward global prophetically willed war against the West.

Fourthly, the article relates these developments to greater extremism among Sunni jihadists whose fratricidal violence is self-defeating yet difficult to combat. The rise of the Islamic State embodies these fanatical sectarian and apocalyptic orientations. The Islamic State's seizure of territory across Iraq and Syria in 2014 and subsequent proclamation of a "caliphate" inspired sharp internal divisions within the jihadist world undermining Al Qaeda's direction of the global jihadist movement. ${ }^{26}$

Al Qaeda has historically rejected sectarian and apocalyptic orientations. The anti-Shia and eschatological discourse of The Islamic State of Iraq -ISI (IS' predecessor) were repudiated by Al Qaeda leaders. ${ }^{27}$ The Islamic State's success in exploiting sectarian tensions is, however, increasingly mimicked by leading Al Qaeda ideologues. Current emir Ayman al Zawahiri and his heir apparent Hamza bin Laden now resort to anti-Shia and anti-Iranian messages. ${ }^{28}$ Such a development speaks volumes about the transcendental importance of sectarian conflict that if anything is growing across the region. The pressures have been building for over a generation.

\section{RESULTS AND DISCUSSION}

\subsection{The Iranian Revolution and its Sectarian Agenda}

The 1979 Iranian Revolution presented manifold challenges to regional and international order. Predating the rise of the Taliban, the Iranian Islamic Republic was the first radical Islamist state of the $20^{\text {th }}$ century that directly challenged U.S. and regional powers. The confluence of Shia revolutionary ideology and past resentments over American and Israeli support for the Shah's repressive regime, fed hatred for the West and its allies. ${ }^{29}$ The 1979 seizure of the American embassy in Tehran by a radical student movement was just one opening salvo of the regime's war against Western interests.

\footnotetext{
${ }^{23}$ Filiu JP.,Apocalypse in Islam (Berkley: University of California Press, 2011)

${ }^{24}$ Gohel SM., ibid

${ }^{25}$ Celso A.,The Islamic State A Comparative History of Jihadist Warfare (Latham, Lexington Books, 2018)

${ }^{26}$ Zelin A.,"The War Between ISIS and Al Qaeda for Supremacy of the Global Jihadist Movement" Research Note 20 The Washington Institute for Near East Policy (June 2014): http://www.washingtoninstitute. org/uploads/documents/pubs/researchnote_20_Zelin.pdf

${ }^{27}$ McCants W.,The ISIS Apocalypse (New York: St. Martin's Press,2015); Filiu JP., Apocalypse in Islam, ibid

${ }^{28}$ Soufan A., "Hamza bin Laden,: From Steadfast Son to Al Qa'ida's Leader in Waiting" CTC Sentinel 10:8 1-7

${ }^{29}$ Eisenstadt M., "The Strategic Culture of the Islamic Republic of Iran: Operational and Policy Implications" MES Monographs Middle Eastern Studies August 2011 accessed at: http://www.washingtoninstitute.org/ policy-analysis/view/the-strategic-culture-of-the-islamic-republic-of-iran-religion-expediency-a
} 
After the end of World War I and until the revolution Iran had been a stalwart ally of the West. Anglo-American oil interests dominated its economy, and security had been guaranteed by military strongman Reza Shah Pahlavi who laid the basis for an autocratic but Westernized Iran. His son and successor Muhammad Reza Pahlavi in the 1950's began a White Revolution to create a secular modern Iran with a dynamic market economy and a Western trained and armed army.

The Shah's undermining of clerical authority over educational and welfare activities engendered strong religious condemnation by Iran's powerful theological establishment. Grand Ayatollah Khomeini emerged as the Shah's arch nemesis whose revered status among the clergy made his opposition to the regime's secularization campaign a difficult political problem. ${ }^{30}$ With his cult following within Iran abetted by his incendiary speeches condemning the Shah's government, Khomeini was forced into exile. Living in Iraq and Europe, the cleric tirelessly inveighed against the excesses of the regime.

He personified opposition to the Shah whose corrupt repressive rule became increasingly unpopular in the late 1970's. Tehran's land reform and modernization policies had impoverished the countryside where religiously was high and the secular state resented. Rapid industrialization of the 1960's and the volatility of oil prices created severe inequalities in Iran's economy and contributed to the growth of a strong communist movement that had imbed in the working class. The Shah's autocratic manner had, furthermore, alienated the liberal middle class.

Protest against government policy in 1978 was met by the regime with repression and army massacres. The Shah's brutality resulted in larger protests. Stricken with cancer and faced with an American Administration unwilling to give his regime a green light to smash the nascent protest movement, the Shah was forced into exile. The resulting power vacuum led to a revolutionary transitional government that degenerated into civil war between opposing communist and Islamist camps. The religious revolutionaries brutally suppressed the communist movement seizing power. Thousands of political opponents were executed and imprisoned. ${ }^{31}$

Proclaimed as the Islamic Republic of Iran the new regime openly challenged Western interests. Built around the principle of vilayat al-fiqah [rule of the jurisprudent), Iran's Constitution institutionalized clerical rule. ${ }^{32}$ The regime's foreign and national security policy would be dominated by a leading cleric chosen by an Assembly of Experts commissioned by a clerical body known as the Guardian Council. Iran's first supreme leader AyatollahRuhollah Khomeini famously called America the Great Satan and committed his regime to the destruction of Israel and the liberation of Palestine. Thirty years after the revolution the regime has consistently pursued policies to damage Western and Israeli interests across the Mideast. ${ }^{33}$

Tehran's patronage of Lebanese and Palestinian groups committed to the destruction of the Zionist state and its support for the anti-Israeli Syrian regime has frustrated the realization of a comprehensive peace in the region. Since the revolution successive Iranian governments have embarked on a sectarian agenda designed to liberate oppressed Shi' ites and aligned groups across the Mideast. Part of this initiative is to safeguard revered holy places, burial sites and shrines in Lebanon, Syria and Iraq from the predations of Sunni radicals that see these sites as polytheistic. The emergence of a theocratic Iran, moreover, threatened Sunni Arab Gulf states fearful that Tehran would encourage sectarian minorities to rebel against their rule.

Tehran's support for Saudi Shia insurrectionary groups in the Kingdom's oil producing eastern region was a particular pressing concern for the royal family that gave its security services carte blanche to quell any nascent rebellion. With Shia and aligned populations in Iraq, Syria, Bahrain, Yemen and Lebanon, Tehran's hoped to build an Iranian arc of influence that stretched from Baghdad to Beirut. ${ }^{34}$

\footnotetext{
${ }^{30}$ Nasr V., ibid 117-143

31 ibid

${ }^{32}$ ibid

${ }^{33}$ Eisenstadt M., ibid

${ }^{34}$ Ghaddar H., Iran's Foreign Legion: The Impact of Shia Militias on US Foreign Policy" Policy Notes Washington Institute for Near East Policy 2018 accessed at: http://www.washingtoninstitute.org/policy-analysis/view/irans-foreign-legion-the-impact-of-shia-militias-onu.s.-foreign-policy
} 
Such a pan -Shia project (now a distinct possibility) could reorder the geo-political power across the Mideast and position Tehran with the capacity to severely undermine Israeli security.

Since the early 1980's Iran has waged an asymmetric -hybrid warfare against the Zionist state. The 1982Israeli occupation of Lebanon provided a major strategic opening for Tehran to develop a Shia insurgent force. ${ }^{35}$ Spearheading this development would be Islamic Revolutionary Guard Corps (IRGC) trainers and generous financial and armaments assistance.

This support eventually culminated in the development of Lebanese Hezbollah insurgent and terror network. Its operations have been ruthlessly effective. Hezbollah forced the disengagement of American and French peacekeepers from Lebanon in the early 1980's and made Israel's occupation of South Lebanon so costly that in 2000 Jerusalem withdrew its forces. Over a thousand Israeli military personnel died in the group's ambushes and suicide bomb attacks. ${ }^{36}$

Hezbollah's military capabilities matured during Jerusalem's eighteen year Lebanese occupation. Israel's withdraw from South Lebanon in 2000 allowed Hezbollah to create a network of underground tunnels and accumulate an immense arsenal of Iranian supplied short and medium range rockets.

Central to Hezbollah's development was Tehran's ability to run its weapons through Syria whose Alawite dominated government and refusal to sign a peace accord with Israel, made Damascus a sectarian and strategic partner. Iranian and Syrian support allowed Hezbollah and Palestinian Hamas to launch in 2006 attacks against Israel troops. The resulting war proved to be a publicity boon for Hezbollah and its Iranian patron. ${ }^{37}$ The Shia militia's capacity to survive a month long struggle with Israeli forces contrasted strikingly with past Arab military defeats against the Zionist state.

Iran's development of Hezbollah military capabilities since the 2006 war has progressed further allowing it to develop an expeditionary force capable of offensive operations. Geopolitical volatility has assisted Iran's historic efforts to project a Pan-Shia sphere of influence across the Mideast. Both the 2003 U.S. led Iraq war and the Arab Spring's turmoil have facilitated this project. Today Iraqi, Syrian and Yemeni instability are the wellspring of Iran's expanded footprint in the region.

\subsection{The 2003 Iraq War, the Arab Spring and the Syrian Crisis}

Though the growth of Iranian power in the region is natural trajectory of the regimes expansionist policy, it has been abetted by events beyond Tehran's control. The American led war to overthrow Saddam Hussein's Baathist regime and its incubation of a fragile democratic system politically empowered the Shia majority and became a conduit for Iranian influence across the country.

The development of close ties between Bagdad and Tehran did not surprise Sunni Gulf states that were unanimous in their opposition to the 2003 war. These states feared that Iran could use Iraq as a base for future destabilization by supporting Shia militant groups in Saudi Arabia, Bahrain and Yemen. The course of subsequent events has proved these fears as prescient.

Iran's geographic proximity to Iraq and the close religious and cultural ties between their respective Shia communities made Tehran a natural economic and political partner. ${ }^{38}$ The Shia clerical establishment in these countries were moreover inextricably linked. Many Iraqi clerics trained in Iran and thousands of Iranian pilgrims visited Iraq revered religious sites. ${ }^{39}$

The presence of tens of thousands of American troops as an occupation force provided a strategic opening for Iran's IRGC to strike against Western coalitional forces. After Hussein's fall Tehran financed, trained and armed Shia militant groups. Using its Lebanese Hezbollah model, Tehran created dozens of Shia militias who in turn spawned a vast network of charitable and political organizations. Today such groups known as Popular Mobilization Forces (PMF) are a backbone of

\footnotetext{
${ }^{35}$ Gleis J., "Withdrawing Under Fire: Lessons Learned from Islamist Insurgencies Washington D.C.: Potomac Books:, 2011)

${ }^{36}$ Jibid $79-122$

${ }^{37}$ Harel A. and Issacharoff A.,34 Days: Israel, Hezbollah and the War in Lebanon (Palgrave McMillian, 2008)

${ }^{38}$ Nasr V., ibid 183

${ }^{39}$ Ibid
} 
Iraq's security forces not directly under Baghdad's control. ${ }^{40}$ They number in the hundreds of thousands.

During the Iraq war the most dangerous Shia militiato Western troops in Iraq were the brigades associated with the cleric Muqtada al-Sadr. HisJaysh al-Mahdi or Mahdi army were a vital part of the Iraqi Shia resistance to coalitional forces battling them throughout the eight year U.S. occupation of the country ${ }^{41}$. Hundreds of American troops and thousands of Shia militiamen died in these battles. ${ }^{42}$ By calling his political-paramilitary force the Mahdi army al-Sadr evoked apocalyptic images of a prophesied redeemer who would vanquish injustice and lay the foundation for Islamic conquest of the world.

The advent of Iraqi democratization created a dysfunctional precedent that contributed to the Arab Spring's upheavals some eight years later. Though the Iraq war may have aggravated populist resentment against regimes in Tunisia, Egypt, Libya, Yemen and Syria it pales in comparison to internal forces that had been building for generations. Government oppression, economic stagnation, corruption, state illegitimacy and youth unemployment drove the 2011 populist protests that toppled governments in Tunisia, Egypt, Libya and Yemen. ${ }^{43}$

Western analysts misread the Arab Spring as signalling a Mideast democratization that would undermine the jihadist movement. Many interpreted the role of social media by young activists and their use of nonviolent civil disobedience as evidence of the Mideast's liberal democratic moment. ${ }^{44}$ Ignored at the time was the role of Islamist civil society in the protest movement that would carry the protest movement in a very different direction. ${ }^{45}$

This was soon seen in the election of Islamist parties in Tunisia and Egypt and the emergence of jihadi groups in the Yemeni, Syrian and Libyan revolts. ${ }^{46}$ Far from weakening Islamic extremism it empowered it aggravating the jihadist movement's most barbaric tendencies. The departure of American troops in Iraq proved an additional boon to the Islamic State of Iraq (ISI) weakened but not vanquished terror-insurgent network.

Though degraded by US counter-terror policies and Sunni militias, ISI capitalized on sectarian tensions running across the region exacerbated by Prime Minister Nuri al-Maliki's repression of the Sunni minority. ${ }^{47}$ Popular revolts in Syria gave an additional impetus for jihadist mobilization linked to Al Qaeda and ISI. The growth of Sunni extremist movements in countries stratified along sectarian faultiness has stimulated the rise of Iranian backed Shia militias exacerbating the violence raging in Iraq, Syria, and Yemen. Given their fragile confessional fault lines, the sectarian blood- letting could spread to Bahrain and Lebanon. ${ }^{48}$

With the unmooring of the regional state system the Mideast now is at the intersection of two sectarian cross currents that are tearing it apart. The development of a trans-national Sunni jihadist

\footnotetext{
${ }^{40}$ Doering D., "Washington's Militia problem in Syria is an Iran Problem" Policy Watch 2932 Washington Institute for Near East Policy February 2018 accessed at: http://www.washingtoninstitute.org/policyanalysis/view/washingtons-militia-problem-in-syria-is-an-iran-problem

${ }^{41}$ Smyth P., "Beware of Muqtada al-Sadr" The Washington Institute for Near East Policy October 19, 2016 accessed at:

${ }^{42}$ Ibid

${ }^{43}$ New Arab Revolt: What Happened, What it means and What Happens Next? ( New York: Council of Foreign Relations/Foreign Affairs:, 2011)

${ }^{44}$ Bergen P.,The Longest War: The Enduring Struggle between the United States and Al Qaeda (New York: Simon and Schuster, 2010); The New Arab Revolts, ibid

${ }^{45}$ Feiler B.,Generation Freedom: The Mideast Uprisings and the Remaking of the Modern World

${ }^{46}$ Byman D., "How Secular Uprisings Could Help (or Hurt) Jihadists" Foreign Affairs May/June 2011: Gartenstien-Ross D. and Zelin A., "How the Arab Spring Prisoner Release Programs Have Helped the Jihadi Cause The Atlantic October 11, 2012 accessed at http:www.washingtoninstitute.org/policy-analysis/view/howthe-arab-spring-prisoner-release-program-has-helped-the-jihadi-cause.php

${ }^{47}$ Pollack K., "The Fall and Rise and Fall of Iraq" July 30, 2013 Bookings Institution http://www.brookings. edu/research/papers/2013/07/30-fall-rise-fall-iraq-pollack.pdf; Cordesman A., Iraq in Crisis Center for Strategic and International Studies access at http://csis.org/files/publication/140421_Iraq_book.pdf.

${ }^{48}$ Knights M. and Levitt M., "The Evolution of Shi's Resistance in Bahrain" CTC Sentinel 11:1 18-24; Schenker D., "Syria's Instability Reaches Lebanon" December 20, 2012 Washington Institute for Near East Policy accessed at:
} 
force linked to Al Qaeda and the Islamic State has received a great deal of attention. Richard Barrett in his study of foreign fighters notes that by 2015 some forty to fifty thousand fighters from ninety different countries have travelled to Syria and Iraq for fight for Sunni extremist networks. ${ }^{49}$

With the collapse of IS' caliphate and the weakening of the AQ linked jihadist movement in Syria analysts increasingly worry about the return of these fighters to the native lands. ${ }^{50}$ The development of a transnational Sunni force has been matched by Islamic Revolutionary Guard Corp(IRGC) and Hezbollah incubation of a multinational Shia militia force.

Tehran has recruited and armed some 40,000 Iraqi, Pakistani, Afghan Shia volunteers to defend the Assad regime. ${ }^{51}$ Combined with Hezbollah the IRGC led Shia expeditionary force in Syria numbers close to 50,000 fighters that have assisted Damascus efforts to fend off rebel forces. ${ }^{52}$ Along with Russian airpower, Tehran's pan-ethnic army has been credited with assisting Assad's re-conquest of two thirds of the country. ${ }^{53}$ This force is poised to fight the remaining bastion of Al Qaeda linked jihadist fighters in rebel held Idlib Province. ${ }^{54}$

More alarmingly such a force could be used in future wars against Israel or deployed to fight against Sunni regimes in sectarian mixed societies. The presence of such a large pan-Shia force in Syria complicates finalizing military operations against the Islamic State's weakened insurgent-terror movement. Many of the underlying intra-confessional antagonisms that gave impetus to the Post Arab Spring conflicts in Iraq and Syria have not been resolved. Given the tensions political conditions for the reactivation of a Sunni extremist movement remain.

Though its state building project has been derailed by an international coalition of forces the Islamic State remains a potent insurgent-terrorist movement. ${ }^{55}$ If the past is any judge the IS movement like its ISI progenitor could rebuild its damaged network. Though the United States has committed itself to liquidate remaining IS positions in the Euphrates River Valley, declarations by the Trump Administration that it could withdraw American forces from Syria augers the possibility of IS reemergence. $^{56}$

Al Qaeda associates in Syria similarly have not been destroyed. The network retains a vigorous presence in Idlib Province and hopes to capitalize on the Islamic State's weakening. ${ }^{57}$ With sectarian wars and tensions building across the Mideast, the progressive extremism of the Sunni jihadist movement is likely to continue.

\subsection{Sectarian Conflict and Jihadist Radicalization}

This growth of Iranian Shia expansionism in the region strengthened by the Iraq War and the Arab Spring has been met by Sunni jihadist resistance. Though fiercely opposed to each other, Shia and Sunni extremists have exploited the dissolution of Mideast states. The clash between the two opposing forces amplifies the violence convulsing the region.

The spread of Iranian power within the region has been met with a corresponding growth of Sunni jihadist movements. The Islamic State and Al Qaeda fight Hezbollah and Shia militias across Iraq and

\footnotetext{
${ }^{49}$ Barrett R., 'Foreign Fighters: An Updated Assessment of the Flow of Foreign Fighters into Syria and Iraq The Soufan Group December 2015 accessed at http://www.soufangroup.com/wp-content/uploads/2015/12/TSG_ ForeignFightersUpdate3.pdf

${ }^{50}$ Hegghammer T., "The Future of Jihadism in Europe: A Pessimistic View" Perspectives on Terrorism 10:6 $156-170$

${ }^{51}$ Ghaddar H., ibid

${ }^{52}$ Eisenstadt M., "Has the Assad Regime 'Won' Syria's Civil War" The Washington Institute for Near East Policy May 15, 2016 accessed at: http://www.washingtoninstitute.org/policy-analysis/view/has-the-assadregime-won-syrias-civil-war 53 ibid

${ }^{54}$ Balanche F., "Preventing a Jihadist Factory in Idlib Province" Policy Watch 2856 Washington Institute for Near East Policy August 2017 accessed at: http://www.washingtoninstitute.org/policy-analysis/view/preventinga-jihadist-factory-in-idlib

${ }^{55}$ Celso A., The Islamic State: A Comparative History of Jihadist Warfare, ibid

${ }^{56}$ Bendaoudi A., "Will U.S. Policy Allow IS to Re-emerge" June 21, 2018 The Washington Institute for Near East Policy accessed at:

${ }^{57}$ Balanche F., "Preventing a Jihadist Factory in Idlib Province" ibid
} 
Syria, and AQ's Yemeni branch is pitted against Shi'ite Houthi rebels. Jihadi groups increasingly tie Shia Iran to a nefarious Zionist-Crusader conspiracy in their ideological discourse.

The $13^{\text {th }}$ edition of the Islamic State's English language magazine Dabiq entitled The Rafidah: From bn Saba to the Dajaal describes the Shia as a heretical apostate group with Jewish origins that are driven by a pathological need to corrupt and destroy Islam. ${ }^{58}$ In Dabiq's words:

These are the rafidah. Initiated by a Jew, they are an apostate sect drowning in the worship of the dead, cursing the best companions and wives of the Prophet, spreading doubt about the very basis of the religion (the Quran and Sunnah), defaming the very honour of the Prophet, preferring their twelve imams to the Prophet and even Allah. ${ }^{59}$.

Dabiq endorses deceased ISI emir Abu Musab Zarqawi's genocidal project against the Shia defending its religious legitimacy. Accordingly, the Shia "must be killed wherever they are found, until no Rafidi walks on the face of the earth." ${ }^{60}$ It presents Shi' ites as devilish companions of the Jews conspiring against the true defenders [Sunnis] of the faith. The sectarian animus of the global jihadist movement has grown appreciably in the last decade

This is even true of Al Qaeda that has in the past rejected targeting the Shia. Though analysts emphasize the 2005 letter written by Aymen al-Zawahiri that sharply repudiated late ISI leader AbuMusab al-Zarqawi's attacks on Shia religious sites as evidence of Al Qaeda's moderation, few paid attention to AQ's historic leader's criticism of the Shia in his correspondence. ${ }^{61}$ Zawahiri calls the Shi' ites "traitors" for "colluding with the Americans" and says that collision with the Shia is "inevitable". ${ }^{2}$ Zawahiri inveighs against the Shi' ism calling it a "religious school based on falsehood and excess" and urges Zarqawi to wait until the mujahidin movement is stronger before confronting the Shia. ${ }^{63}$

Since this time, Al Qaeda has hardened its attitude toward the Shia and Iran even further. There are a number of reasons for this transformation. First, Al Qaeda is a fractured decentralized network incapable of controlling the behaviour of its regional branches. Bin Laden Abbottabad correspondence openly laments the near enemy and sectarian focus of his affiliates. ${ }^{64}$ Even within regional branches top leaders were unable to control the sectarian brutality of local commanders. AQIM's AbdulmalekDrukdel in 2012 rejected the destruction of Sufi architecture in Timbuktu and the draconian punishments imposed by his local commanders, while AQ linked leader Abu Mohammad al-Golani openly denounced his network's massacres of Druze communities. ${ }^{65}$

Frustrated with their inability to control the activity of local commanders, AQ's leaders now seem more willing to accept the sectarian excesses of its members. Second, Iranian patronage of Shia militias in Lebanon, Iraq, Syria, Yemen and Bahrain is seen by Al Qaeda as an effort to destroy Sunni Muslims. Attempting to refashion its signature anti-Western far enemy strategy, AQ leaders tie the Shia to Zionist-Crusader conspiracy to repress righteous Sunnis. Addressing the inter-civilizational clashes that convulse the Muslim world Zawahiri in 2017 stated:

"Our Ummah today is up against a global war in which Eastern and Western Crusaders, Chinese, Hindus, SafaviRawadidh [Iranian Shias] and secular nationalists are partners in crime". ${ }^{66}$

\footnotetext{
${ }^{58}$ Dabiq 13: The Rafidah: From Ibn Saba to the Dajaal, ibid

${ }^{59}$ Ibid 45

${ }^{60} \mathrm{Ibid}$

${ }^{61}$ Barr S. and Minzili Y., "The Zawahiri Letter and Strategy of Al Qaeda" available at http://www.currenttrends ./op...thezawahirikms./.isn.

62 "Letter signed by Zarqawi, seized in Iraq in 2004" reprinted in Brisard, JC.,Zarqawi: The New Face of Al Qaeda (Other Press: New York, 2005) Appendix VIII 233-251; Barr S. and Minzili Y., ibid

${ }^{63}$ ibid

${ }^{64}$ Letters from Abbottabad ibid

${ }^{65}$ Siegel P. "AQIM's Playbook in Mali" Combating Terrorism Center at West Point at West Point CTC Sentinel 6 (2013 ) 9-12; Loveluck, L and Samaan M., "Al Qaeda fighters massacre Druze villagers" The Telegraph June 11, 2015 accessed at: https://www.telegraph.co.uk/news/worldnews/middleeast/syria/11667731/Al-Qaedafighters-in-Syria-massacre-Druze-villagers.html

${ }^{60}$ Joscelyn T., "Zawahiri lectures on global jihad, warns of national boundaries" June 10, 2017 The Long War Journal accessed at: http://www.longwarjournal.org/archives/2017/06/zawahiri-lectures-on-global-jihad-warnsof-national-boundaries.php
} 
Zawahiri efforts to embolden Al Qaeda's faltering far enemy can be seen in his elevation of Hamza bin Laden with the network's central hierarchy. ${ }^{67}$ As Osama's youngest son, Hamza status within A1 Qaeda is a potent reminder of the network's 9-11 attacks. After the American toppling of the Taliban Hamza and much of bin Laden's family lived in exile in Iran where his activity was strictly controlled. Though Tehran had cooperated with Al Qaeda during the pre-9-11 period, its relationship with the Sunni jihadist organization has always been problematic. ${ }^{68}$

Throughout 2017 Hamza bin Laden in his speeches inveighed against the United States, Israel and Russia frequently evoking a conspiratorial world view. In his analysis of Hamza's audio addresses Ali Soufan argues that the young bin Laden's messages are increasingly sectarian. ${ }^{69}$ Like Zawahiri, Hamza warns of "International Crusader-Rafidhi aggression" against Sunnis. Whether it is the Islamic State or Al Qaeda Sunni jihadist messaging has an anti-Shia tone. The violent sectarian clashes between Sunni and Shia radicals evoke images of fitnah a prophesied period of intense intraMuslim division presaging the end of the world.

\subsection{Apocalyptic Ruminations}

Sunni and Shia beliefs in Islamic prophetic hadith [reported statements of the Prophet Muhammad about future events] have engendered further extremism. Some hadith suggest that the Prophet hinted at a period of internal turmoil [fitnah] within the Muslim world that presages the coming of the Mahdi who would revitalize the Islamic faith by aligning it more closely to Allah's divine intent. ${ }^{70}$ Having quelled intra-Muslim divisions and unified the Islamic world, the Mahdi leads Muslim armies in the Levant against devilish Christian Crusaders.

This battle triggers Jesus' descent from heaven and an apocalyptic defeat for satanic forces. The vanquishing of the devil's army leads inexorably to the spread of Islam across the world and the achievement of universal happiness. Within the Shia "twelve" tradition the Mahdi is a revered medieval cleric who lays in suspended animation and whose reappearance is a precursor to the apocalypse. ${ }^{71}$ Shia militias operating in Iraq and Syria frequently evoke apocalyptic motifs and symbols. ${ }^{72}$ Many justify their military involvement as paving the way for the Mahdi's return.

The twelve school interpretation is considered heretical by Sunni extremists who inveigh against the polytheistic foundations of Shia beliefs. In his book Islamic Apocalypse Jean Pierre Filiu notes the reemergence of Islamic eschatological beliefs at the end of the twentieth century. Across the Sunni and Shia divide the study of prophetic hadith and treatises associated with their investigation is growing. ${ }^{73}$ The titanic events affecting the Muslim world from the 1979 Iranian revolution, the successful Afghan jihad of the 1980's and the catastrophic 9-11 attacks are seen by some as harbingers of the end times.

The upheavals in the region have invited similar sentiments. Sunni and Shi'ite extremists believe that the Syrian civil war and the sectarian violence that rages across the Mideast represents fitnah whose resolution paves the way for divinely guided Islamic conquest of the globe. Such beliefs penetrate the very depths of Islamic State ideology. Its main line English magazines Dabiq and its successor Rumiyah are inspired by such eschatological beliefs. ${ }^{74}$

Jihadi fixation on prophetic signs of the hour that harbinger the end times is not an IS philosophical innovation. The $19^{\text {th }}$ century Mahdists who challenged the British Empire in the Sudan where driven by eschatological beliefs. ${ }^{75}$ The 1979 Mecca Grand Mosque seizure by Juhayan al-Otaybi apocalyptic

\footnotetext{
${ }^{67}$ Soufon A., ibid

${ }^{68}$ Moghadan A., "Marriage of Convenience: The Evolution of Iran and Al Qa'ida Tactical Cooperation" CTC Sentinel 10:4 12-18

${ }^{69}$ Soufan A., ibid

${ }^{70}$ McCants W, The ISIS Apocalypse, ibid); Filiu JP., Apocalypse in Islam, ibid

${ }^{71}$ Filiu JP., ibid 141-164

${ }^{72}$ Smyth P., "The Shi'ite Jihad in Syria and its Regional Effects" 2015 The Washington Institute for Near East Policy accessed at:

${ }^{73}$ Filiu JP., ibid, 80-103

${ }^{74}$ Celso A., "Dabq: The Islamic State's Apocalyptic $21^{\text {st }}$ Century Manifesto" Journal of Political Science and Public Affairs 2:4

${ }^{75}$ Celso A., "The Islamic State and the Sudanese Mahdiyyah: A Comparative Analysis of Two Apocalyptic Jihadist States" International Journal of Political Science 4:1 28-42
} 
cultis another example. Believing its movement was divinely guided Juhayan's group declared one of its leaders the Mahdi hoping its mosque seizure would trigger apocalyptic events. ${ }^{76}$ After a tense four week mosque siege, Saudi and French Special Forces put an end to the crisis. During the raid the selfappointed Mahdi and many of his followers were killed. Surviving cult members were subsequently tried and most were executed.

Brookings Institution scholar William McCants argues that IS' predecessor the Islamic State of Iraq (ISI) viewed one of its leaders as the Mahdi and that its formation of a Sunni jihadist state in 2006 was designed to spark divine intercession. ${ }^{77}$ ISI's Post- Zarqawi leaders Abu Hamza-Muhajir and Abu Umar al-Baghdadi emphasized apocalyptic and sectarian orientations. Faced with targeted assassination by U.S. Special Forces and an anti-Al Qaeda rebellion in Anbar Province the group's delusions may have been a psychological reaction to severe adversity. According to McCants, the ISI's decline and the killing of its key leaders in 2010 prompted a reformulation of its apocalyptic messaging.

Re-invigorated under Abu Bakr al-Baghdadi IS' eschatological messages emphasize the group's role in preparing for the Mahdi's emergence and its media organs prioritize the caliphate as a prophetic mechanism to purify the Muslim world and defeat crusader and Shi'ite apostate forces. This caliphate centric focus was officially proclaimed in July 2014 by IS emir Baghdadi. His Mosul Grand Mosque sermon separates the world into competing belief systems pitting virtuous Muslims against devilish apostates. $^{78}$

IS"s caliphate was viewed by its propagandists as a transitional stage to unite Muslims against diabolical forces. Its English language magazine Dabiq emphasized Caliph Ibrahim religious authority and his commitment to the prophetic method. ${ }^{79}$ IS does not claim that Baghdadi is the Mahdi. His familial line, however, IS ideologues argue can be traced to the Prophet's tribe and his $\mathrm{PhD}$ in Islamic studies give him religious legitimacy. ${ }^{80}$ Baghdadi like his ISI and AQI predecessors is viewed as part of a eschatological chain that IS believes will culminate into an apocalyptic war against Shia and Crusader enemies. Based upon their reading of prophetic hadith IS' victory is seen by its partisans as preordained.

The Islamic State's apocalyptic message reaches down to its militants beliefs. Labelled as plebeian jihadism Danish researcher Anne-Sophie Hemmingsen argues that millenarian beliefs are a key force why many Danes joined the Islamic State. ${ }^{81}$ Some Islamic State followers are driven by what they consider are apocalyptic visions and dreams. ${ }^{82}$ The movement's evisceration of Shia mosques, Christian architecture, Sufi burial sites, is slaughter of the polytheistic Yazidi minority, is defacement of Sufi graves and its destruction of pagan Roman and Assyrian monuments are driven in part by a need to redeem Islamic practice and prepare the Muslim umma [community] for an inevitable apocalyptic encounter with the satanic West. The Islamic State's fusion of eschatological and sectarian values in their world view is, moreover, a result of the radicalization of the jihadist movement. ${ }^{83}$

\footnotetext{
${ }^{76}$ Hegghammer T. and Lacroix S., The Meccan Rebellion: the Story of Jubayan al-UtaybiRevisisted(Bristol: Amal Press, 2011)

${ }^{77}$ McCants W., "ISIS and the Absent Mahdi: Studies in Cognitive Dissonance and Apocalyptic Jazz" presentation before Generation Caliphate: Apocalyptic Hopes, Millennial Dreams and Global Jihad Conference Center for Millennial Studies Boston University May 3-4, 2015 accessed at: http://www.bu.edu/history/newsevents/lecture-series-generation-caliphate-apocalyptic-hopes-millenial-dreams-global-jihad/

${ }^{78}$ Dabiq 1 (2014) "From Hijrah to Khalafah: The Return of the Khalifahal-Hayat Media Center http://www.jihadology.net/2014/07/05/al\%e\%68\%sayat-media-center-presents-a-new-issue-of-the-islamic-statemagazine-dabiq1/ ;

79 Ibid.

${ }^{80}$ Anderson A., "Abu Bakr al-Baghdadi and the Theory and Practice of Jihad" Small War Journal August 1, 2014 accessed at http://wwwsmallwarjournal.com/author/gary-anderson

${ }^{81}$ Hemmingsen AS., "Plebian Jihadism in Denmark: An Individualization and Popularization Predating the Growth of the Islamic State" Perspectives on Terrorism 10:6 102-108

${ }^{82}$ Edgar IR., "The Dreams of the Islamic State" Perspectives on Terrorism 9:4 72-84

${ }^{83}$ Celso A., The Islamic State: A Comparative History of Jihadist Warfare, ibid
} 


\subsection{The Building Blocks of Jihadist Extremism}

Extremist fanaticism is a natural progression of jihadism's core ideology whose elastic quality invites ever more expansionist interpretations. Here religious extremism and frustration of not being able to secure a genuine Islamic state play a decisive role in jihadism's radicalized evolution. Failed jihadist movements in Egypt, Algeria, Libya and Syria during the 1980's and 1990's led jihadist strategists to conceive of more extremist doctrines. Frustrated with not having defeated the near enemy of Muslim apostate states Al Qaeda developed its far enemy strategy of attacking the United States hoping to invite an American disengagement from the Mideast. ${ }^{84}$

Having failed to do drive American forces from the region Al Qaeda increasingly has moved to conspiratorial world view that ties Muslim apostate regimes to an International Zionist-CrusaderRafidah world order. The confluence of jihadist frustration and theological fervour contribute to the movement's hyper violent world view. A Weltanschauung where it's founding principles (al- wala, wal-bara', takfir and jihad) have strengthened over time.

The doctrine of loyalty and disavowal (al-wala' and wal-bara') divides believers from non-believers imbuing the latter with demonic qualities. ${ }^{85}$ It speaks to a umma governed by a shared faith that dissociates from others. The doctrine delineates a world of virtuous belief and an outside order governed by wickedness. It aspires to resurrect a community consistent with early Islamic practice whose ideal is Muhammad's Medina community.

By constructing a refuge separate from apostasy, jihadists hope to expand their micro-community through preaching, war and conquest. Nelly Lahoud argues al- wala', wal-bara' is a key principle of the jihadist movement ${ }^{86}$. It is, moreover, an individuated concept for each jihadist determines the community's standards. Given such variances, internal conflict arises. This tendency may explain the violent factionalism within the jihadist movement exemplified by the rivalry between Al Qaeda and the Islamic State.

Al-wala', wal-bara's propensity for violence is rooted in early Islamic history. The Kharajites were so wedded to Muhammad's Medina ideal that they rebelled against his immediate successors for their Quranic deviations. ${ }^{87}$ Their desire to create an ideal micro-culture led them to expel those whose faith they questioned. Early Islamic rule was convulsed by internecine violence driven by theological conflicts and power struggles. ${ }^{88}$

Al-wala', wal- bara' contributes to a takfirist world view. Jihadists decouple from the world separating good from evil. This invites resistance against apostate forces. Since jihadists view Muslim society as stricken by post-Islamic ignorance [jahiliyyah] most co-religionists are apostates. ${ }^{89}$ Violent Islamic extremists see these societies as terminally ill for they venerate man's law over God's rightful sovereignty (hakimiya). Jihadists view societal ignorance as so pronounced that that missionary preaching $\left[d a^{\prime} w a\right]$ has little impact.

If mujahidin are to perform their divinely mandated mission to purify Islam they must resort to violence against regime supporters. With theological prohibitions against murdering fellow Muslims, this requires co-religionists expiation from the faith. Historically takfir was practiced selectively against impious individuals subject to clerical adjudication. ${ }^{90}$

Over time, however, jihadists expanded takfir's scope. Some expiations are political (regime officials and their supporters) others sectarian [Shi'ites, Alawites and Druse) and some reflect intra-jihadist quarrels. The latter is seen in the fighting between the Islamic State and Al Qaeda. ${ }^{11}$ Takfirists often

\footnotetext{
84 "Letter to Nasir al-Wuhayshi" Combatting Terrorism Center at West Point Harmony Program document accessedat: https://www.ctc.usma.edu/v2/wp-content/uploads/2013/10/Letter-to-Nasir-al-Wuhayshi-Translation. pdf

${ }^{85}$ Lahoud N., Jhadis Path to Self-Destruction (London: C Hurst and Company, 2010))

${ }^{86}$ Ibid. 49-56

87 57-96

${ }^{88}$ Karsh E., ibid 10-43

${ }^{89}$ Calvert J., SayyidQutb and the Origins of Radical Islam ( London: Oxford University Press, 2009)

${ }^{90}$ Mozaffar M., "What is Islamism: History and Definition of a Concept" Totalitarian Movements and Political Religions, Vol. 8, No. 1, March 2007, pgs. 17-33.

${ }^{91}$ Zelin A., The War Between ISIS and Al Qaeda for Supremacy of the Global Jihadist Movement", ibid
} 
reference IbnTaymiyyah medieval rulings on apostate Mongol Muslim rulers, Shi' ites, Alawites and Duse interpreting them broadly. ${ }^{92}$ Abu Musab al-Zaraqwi, for example, expanded Taymiyyah ruling that Shi'ite leaders must be killed into a genocidal campaign against the Shia. ${ }^{93}$

Resorting to takfirist excommunication legitimates killing Muslims. By doing so jihadists defend alwala' wal- bara' preserving its communal virtue. This requires a strategy of offensive warfare [jihad] to ensure the umma's purification and expand its governance project.

Jihad's meaning inspires heated disputes. ${ }^{94}$ Multiple interpretations engender complex doctrinal and definitional debates. Historically jihad involved personal struggle with one's faith (greater jihad) and defensive war [lesser jihad]. Violent Islamists have expanded it to include aggressive warfare against apostates and their infidel masters. It is a strategy of expansive war that seeks the annihilation of all enemies.

Jihadist doctrine aspires to create a puritanical Islamist micro-culture. Despite their opposition to the Islamic State's caliphate, Al Qaeda ideologues envision an emirate to lead the global jihadist struggle. Abu BakrNaji, for example, advocates creating a nascent jihadist state from disorder and upheaval. ${ }^{95}$ Once implanted this micro-community would serve as an insurrectionary jihadist vanguard to provoke regional destabilization and lay the basis for inter-civilizational war.

Naji's book The Management of Savagery is viewed as the Islamic State's model for warfare and Sharia governance. ${ }^{96}$ In the first issue of Dabiq IS sketches Naji prescribed path to power falsely attributing these stages to Al Qaeda in Iraq (AQI) founder Abu Musab al-Zarqawi. ${ }^{97}$ The Islamic State saw its administrative headquarters in Raqqa (now destroyed) as anew Medina and as the caliphate's governing model. AymenJawad al-Tamimi, for example, argues that Raqqa's administrate rulings were extended throughout IS's Iraqi-Syrian wilaya [provinces]. ${ }^{98}$

\section{CONCLUSION}

Al-wala', wal- bara', takfir and offensive jihad provide the intellectual core of Islamist extremism. These principles propel the movement into greater violence and savagery. Jihadism's community of believers is exclusively narrow. Having rejected the contemporary Muslim world, jihadists hope their violence against the apostate order will spur apathetic Muslim masses into supporting their movement.

Their inability to secure majoritarian support leads jihadists to embark on the killing of Muslims. A Muslim world convulsed by political and sectarian conflicts exacerbates the jihadist movement's most barbaric and fanatical tendencies. Growing apocalyptic sentiment within jihadist groups, moreover, leads them to demonize those who reject their cause propelling them into progressively more brutal violence. Iran's projection of political and military influence across the Mideast has contributed toward the Sunni jihadist movement's sectarian and apocalyptic orientations and pursuit of a final war against near, far and sectarian adversaries. The late Islamic State propagandist Abu Muhammad alAdnani once proudly declared that the caliphate was at "war with the world". ${ }^{99}$

\footnotetext{
${ }^{92}$ Bassiouni MC.," Evolving Approaches to Jihad: From Self-Defense to Regime Chang Political Violence" Chicago Journal of International Law 8:1 ; Ghabadzeh N. and Kbarzadea SA., "Sectarianism and the Prevalence of "othering" in Islamic Thought" Third World Journal 36:4 691-704; HS. Timoni, "The Islamic Context of Global Jihadism : Why IbnTaymiyyah Matters? I Chapter 3 in Underwood L., (ed), The Root of All Evil: Religious Perspectives on Terrorism( New York: Terrorism Studies:, 2013)

${ }^{93}$ Kazimi N., Syria through Jihadist Eyes ( Stanford: Hoover Institution, 2010)

${ }^{94}$ Moghadan A., "Salafi Jihad as a Religious Ideology" CTC Sentinel, (February 2008) Vol. 1, Issue 3

${ }^{95} \mathrm{Naji}$ AB., Management of Savagery available at http://www.vcfia.harvard.edu/olin/images/management $\% 20$ of $\%$ savagery\%20\%2005-23-2006.pdf

${ }^{96}$ Ryan MWS., "ISIS and Al Qaeda: Tactical Twins, Strategic Enemies" Terrorism Monitor 13:24 21-24

${ }^{97}$ Dabiq 1 The Return of the Khalifahh, ibid34-40

${ }^{98}$ al-TamimiAJ.,"The Islamic State's Educational Regulations in Raqqa" August 28, 2014 AymennJawad alTamimi Blog accessed at http://www.aymennjawad.org/2014/08/the-islamic-state-educational-regulations-inraqqa.

99 al Adnani AM., "That They Live by Proof" An Address by the Official Spokesman of the Islamic State The MujahidShaykh Abu Muhammad al-Adnani ash Sham (May Allah Safeguard Him) Al Hayat Media Center May 21, 2016 accessed at http://www.pietervanostaeyen.com/2016/05/22/abu-muhammad-al-adnani-address
} 
Despite being competitors the Islamic State and Al Qaeda fight all who oppose them. They subscribe to a conspiratorial totalitarian world view that their opponents have formed a demonic alliance composed of Muslim apostates, the Shia and Zionist-Crusaders. Their fanaticism leads them toward a self-destructive yet resilient path. As Mohammad Hafez argues fratricidal jihadist violence is engrained in the fabric of Islamist extremism contributing to its failures. ${ }^{100}$ This is exemplified by the meteoric rise and fall of the Islamic State's caliphate.

Fratricidal jihadis he argues fail to learn from past mistakes. ${ }^{101}$ Their dream of erecting a modern version of Islam's golden age through violent insurrection endures. Distressingly jihadist fanaticism propelled by doctrinal, sectarian and apocalyptic sentiments augers a resilient if unsuccessful permanent war. This is a reality that we in the West must face.

Citation: Anthony N. Celso. "Sectarianism, State Failure and the Radicalization of Sunni Jihadist Groups". International Journal of Political Science (IJPS), vol4, no.3, 2018, pp.22-35. doi:http://dx.doi.org/10.20431/ 2454-9452.0403004.

Copyright: () 2018 Authors. This is an open-access article distributed under the terms of the Creative Commons Attribution License, which permits unrestricted use, distribution, and reproduction in any medium, provided the original author and source are credited.

\footnotetext{
${ }^{100} \mathrm{Hafez}$ M., "The Curse of Cain: Why Fratricidal Jihadis Fail to Learn from Their Mistakes" CTC Sentinel 10:10 1-7

${ }^{101}$ Ibid 